\title{
Meningkatkan Hasil Belajar Siswa Pada Materi Sumber Daya Alam Dan Kegiatan Ekonomi Dengan Menggunakan Media Peta Dan Gambar Serta Metode Diskusi di Kelas IV SDN Rawalumbu
}

\author{
Agus Krisdiyanto \\ SD Negeri Rawalumbu \\ krisdiyantoa@gmail.com
}

\section{Article History}

received $3 / 12 / 2020$

\begin{abstract}
This research we conducted with the aim to improve the learning achievementsof students in muatan Social Science lessons natural resources and economic activities in grade IV semester 2 sd Negeri Rawalumbu, Researchers use discussion and observation methods as well as media maps and images as an effort to achieve that goal. From the identification of good data from the observation of learning activities in cycle I, it still has not produced satisfactory results. This can be seen from the average achievement of students who are still under KKM which is 69.28. While skor learning activityis 70.45. In cycle II, theaverage student learning achievement result increasedabove KKM to 77.86. While skor learning activitiesbecame 93.18. Based on the analysis of data in cycles I and II it was concluded that the use of discussion and observation methods as well as map and image mediaimprovedstudents' learning achievements in ips lessons in Natural Resources and Economic Activities.
\end{abstract}

Keywords: IPS, discussion methods, media maps and images

\begin{abstract}
Abstrak
Abstrak dalam bahasa Indonesia mengikuti kaidah dalam Pedoman Umum Ejaan Bahasa Indonesia (PUEBI) Penelitian ini kami lakukan dengan tujuan untuk meningkatkan prestasi belajar belajar siswa pada muatan pelajaran IImu Pengetahuan Sosial materi Sumber Daya Alam dan Kegiatan Ekonomi di kelas IV semester 2 SD Negeri Rawalumbu, Peneliti menggunakan metode diskusi dan observasi serta media peta dan gambar sebagai upaya untuk mencapai tujuan tersebut. Dari hasil identifikasi data baik dari observasi kegiatan pembelajaran pada siklus I, ternyata masih belum membuahkan hasil yang memuaskan. Hal ini terlihat dari pencapian ratarata nilai siswa yang masih di bawah KKM yakni 69,28. Sedangkan skor aktivitas pembelajaran adalah 70,45. Pada siklus II, rata-rata hasil prestasi belajar siswa meningkat di atas KKM menjadi 77,86. Sedangkan skor aktivitas pembelajaran menjadi 93,18. Berdasarkan analisis data pada siklus I dan II disimpulkan bahwa penggunaan metode diskusi dan observasi serta media peta dan gambar dapat meningkatkan prestasi belajar siswa pada muatan pelajaran IPS materi Sumber Daya Alam dan Kegiatan Ekonomi.
\end{abstract}

Kata kunci: IPS, metode diskusi, media peta dan gambar

Social, Humanities, and Education Studies (SHEs): Conference Series https://jurnal.uns.ac.id/shes 


\section{PENDAHULUAN}

pendidikan tidak dapat dipungkiri oleh siapa pun. Dewasa ini, Indonesia terus meningkatkan subsidi pendidikan agar masyarakat menikmati pendidikan. Kesadaran bahwa bangsa dan negara tidak akan maju tanpa pendidikan, menjadi indikasi kepedulian masyarakat terhadap pendidikan (Hamdani, 2011: 14).

Menurut National Concil For The Social Studies (NCSS) (2015) mendefinisikan social studies atau Ilmu Pengtahuan Sosial (IPS) sebagai suatu studi yang terintegrasi dari ilmu-ilmu sosial dan humaniora untuk meningkatkan kemampuan warga negara. Dalam 25 program sekolah, IPS mengkaji secara sistematis dan terkoordinasi berbagai disiplin ilmu seperti antropologi, arkeologi, ekonomi, geografi, sejarah, hukum, filsafat, ilmu politik, psikologi, agama dan sosiologi (Wahidmurni, 2017: 17).

Dapat disimpulkan bahwa IImu Pengetahuan Sosial merupakan salah satu mata pelajaran yang dipelajari oleh siswa sekolah dasar dan menengah yang sederajat, yang mengkaji seperangkat isu sosial yang memuat materi geografi, sejarah, ekonomi, dan sosiologi. Hakikat IPS adalah telaah tentang manusia dan dunianya. Manusia sebagai mahluk sosial selalu hidup bersama dengan sesamanya. Dengan kemajuan teknologi pula sekarang banyak orang berkomunikasi dengan cepat dimanapun mereka berada melalui handphone dan internet. Kemajuan iptek menyebabkan cepatnya komunikasi antara orang satu dengan lainnya, antara negara satu dengan negara lainnya. Dengan demikian arus komunikasi akan semakin cepat pula mengalirnya (Gunawan, 2013: 17).

Pencapaian tujuan pembelajaran IPS guru harus memiliki strategi yang tepat, dengan kata lain guru harus memiliki pengetahuan dan kemampuan dalam menggunakan berbagai metode pembelajaran serta penggunaan media pembelajaran dalam pelaksanaan pembelajaran. Sehingga dalam proses pembelajaran siswa terlibat aktif dan senang mengikuti pembelajaran,dengan demikian hasil belajar siswa akan meningkat.

Pada tahap awal, peneliti melakukan observasi pada kegiatan pembelajaran IPS di kelas IV SDN Rawalumbu pada semester 2 tahun pelajaran 2019/2020 dengan materi yang diteliti adalah Sumber Daya Alam dan Kegiatan Ekonomi. Kegiatan observasi ini mencatat semua kejadian pada kegiatan pembelajaran, dalam rangka untuk identifikasi masalah-masalah yang timbul dalam kegiatan pembelajaran. Berdasarkan data nilai tes formatif studi awal menunjukkan hasil yang tidak memuaskan. Dari sejumlah 14 siswa baru 4 anak yang mencapai penguasaan materi di atas $70 \%$. Selama pembelajaran berlangsung sebagian siswa tidak fokus pada pembelajaran. Banyak anak yang bermain sendiri dan pada waktu guru mengajukan pertanyaan tidak ada yang dapat menjawab dengan benar serta tidak ada anak yang berani bertanya.

Disamping uraian di atas, pada awal kegiatan pembelajaran guru juga tidak menggunakan alat peraga hanya menggunakan metode teks book dan ceramah. Kondisi demikian yang mungkin membuat siswa merasa bosan dan jenuh dengan kegiatan pembelajaran tersebut.sehingga banyak siswa yang tidak fokus terhadap kegiatan pembelajaran di kelas.

Dari penjelasan di atas, maka peneliti berusaha melakukan kegiatan perbaikan pembelajaran. Diharapkan setelah melakukan penelitian nilai rata-rata ulangan di atas KKM (Kriteria Ketuntasan Minimal) kelas, serta keaktifan siswa pun meningkat.

Untuk meningkatkan hasil belajar siswa, peneliti menggunakan media peta dan gambar serta menggunakan metode diskusi dalam pembelajaran tentang sumber daya alam dan kegiatan ekonomi. Diharapkan dengan menggunakan media peta dan gambar serta metode diskusi ini, minat belajar siswa akan meningkat.

Masalah yang dihadapi pada pembelajaran ini adalah hasil belajar siswa kurang, masih banyak yang di bawah KKM. Selain itu guru kurang menggunakan media dan metode yang sesuai dalam penbelajaran. Dengan perbaikan pembelajaran diharapkan kualitas pembelajaran meningkat yang nantinya hasil belajar siswa pun akan meningkat. 
Untuk memecahkan masalah pada pembelajaran sumber daya alam dan kegiatan ekonomi peneliti menggunakan media peta dan gambar serta metode diskusi dipadu dengan metode lain yang relevan.

Berdasarkan uraian di atas, maka perlu untuk melakukan Penelitian Tindakan Kelas yang berjudul "Meningkatkan hasil belajar siswa pada materi sumber daya alam dan kegiatan ekonomi dengan menggunakan media peta dan gambar serta metode diskusi di kelas IV SDN Rawalumbu". Berdasarkan latar belakang di atas, maka rumusan masalah pada penelitian ini adalah "Apakah dengan menggunakan media peta dan gambar serta metode diskusi dapat meningkatkan hasil belajar siswa kelas IV SDN Rawalumbu?". Adapun tujuan penelitian ini adalah secara umum, Untuk Meningkatkan prestasi belajar siswa kelas IV SDN Rawalumbu pada materi sumber daya alam dan kegiatan ekonomi kompetensi dasar mengenal aktifitas ekonomi yang berkaitan dengan sumber daya alam dan potensi lain di daerahnya. Sedangkan secara khusus untuk meningkatkan hasil belajar materi sumber daya alam dan kegiatan ekonomi pada siswa kelas IV SDN Rawalumbu dengan memanfaatkan media peta dan gambar serta metode diskusi. Hasil penelitian diharapkan bermanfaat bagi siswa untuk meningkatkan pembelajaran pada materi sumber daya alam dan kegiatan ekonomi dan bagi guru untuk mengoptimalkan penggunaan media dalam pembelajaran IPS di kelas IV, untuk mencapai tujuan pembelajaran yang diinginkan, sedangikan bagi sekolah untuk meningkatkan mutu pendidikan pembelajaran IPS di SDN Rawalumbu.

Menurut Trianto (2010:5) mengemukakan bahwa belajar adalah kegiatan yang membentuk pola tingkah laku peserta didik sesuai dengan tujuan pendidikan, serta dapat dievaluasi melalui pengukuran dengan menggunakan tes dan non tes. Selanjutnya dikatakan bahwa tes hasil belajar dibuat untuk mengetahui kemampuan siswa. tes hasil belajar merupakan butir tes untuk mengetahui hasil belajar siswa setelah mengikuti kegiatan belajar-mengajar. Tes hasil belajar dibuat dengan mengacu pada kompetensi dasar yang ingin dicapai, dijabarkan kedalam indikator pencapaian hasil belajar dan disusun berdasarkan kisi-kisi penulisan butir soal lengkap dengan kunci jawaban, serta lembar observasi penilaian aktifitas siswa. Fungsi penelitian diperkuat oleh Jensen (2010:68), bahwa fungsi penilaian ini adalah menilai seberapa baiknya siswa telah belajar dan kesuksesan guru mempresentasikan materi. Dan menjadi umpan balik yang dapat memperbaiki pembelajaran.

Media adalah sesuatu yang dapat digunakan untuk menyalurkan pesan, merangsang pikiran, perasaan, perhatian dan kemampuan siswa, sehingga dapat mendorong proses pembelajaran. Menurut Azhar (2011) media pembelajaran adalah alat bantu pada proses belajar baik di dalam maupun diluar kelas, lebih lanjut dijelaskan bahwa media pembelajaran adalah komponen sumber belajar atau wahana fisik yang mengandung materi intruksional di lingkungan siswa yang dapat merangsang siswa untuk belajar.

Hasil belajar adalah "kompetensi atau kemampuan tertentu baik kognitif, afektif maupun psikomotorik yang dicapai atau dikuasai peserta didik setelah mengikuti proses belajar mengajar" (Kunandar, 2013:62).

Berdasarkan uraian dan rumusan masalah maka hipotesis tindakan dalam penelitian ini adalah dengan menggunakan media peta dan gambar serta metode diskusi, dapat meningkatkan hasil belajar siswa kelas IV SDN Rawalumbu pada materi sumber daya alam dan kegiatan ekonomi.

\section{METODE}

Dalam penelitian tindakan kelas ini, Model penelitian ini mengacu pada modifikasi spiral yang dicantumkan Kemmis dan Mc Taggart (Dahlia, 2012:29). Tiap siklus dilakukan beberapa tahap, yaitu 1) Perencanaan tindakan, 2) Pelaksanaan tindakan, 3) Observasi, dan 4) Refleksi. Penelitian ini dilaksanakan 2 (dua) bulan penuh, yaitu pada bulan Januari dan Pebruari 2020. Penelitian ini dilaksanakan di SDN Rawalumbu. 
Subyek penelitian ini adalah seluruh siswa kelas IV yang berjumlah 14 orang siswa, terdiri dari 6 orang siswa laki-laki dan 8 orang siswa perempuan dengan karakteristik dan tingkat kecerdasan yang berbeda-beda.

Dalam penelitian ini, pengumpulan data dilakukan dengan cara : observasi dan tes. Jenis data yang peneliti peroleh dari penelitian tindakan kelas ini adalah data kuantitatif. Data kuantitatif berupa skor kemampuan (hasil belajar) siswa yang di ambil dari ulangan harian setelah tindakan-tindakan, baik tindakan pada siklus I maupun siklus II. Data tersebut diolah dengan menggunakan analisis diskriptif komparatif yaitu membandingkan nilai tes kondisi awal dengan nilai setelah siklus I, dan nilai tes siklus II. Sedangkan kualitatif dianalisa dari hasil pengamatan keaktifan selama pembelajaran.

Dari hasil tes kemudian dianalisis dengan teknik analitas kecenderungan nilai tengah (central tendensi), yaitu mencari nilai rata-rata (mean).

Nilai rata-rata $=\frac{\text { Jumlah nilai seluruh siswa } \times 100}{\text { Jumlah Siswa }}$

Analisis data dari hasil lembar observasi secara kualitatif dengan skala 1-4 dengan skor dan kriteria sebagai berikut :

Tabel 1. Kriteria Nilai

\begin{tabular}{ll}
\hline Nilai & Kriteria \\
\hline $0,0-1,0$ & Kurang sekali \\
$1,1-2,0$ & Kurang \\
$2,1-3,0$ & Cukup \\
$3,1-4,0$ & Baik \\
\hline
\end{tabular}

Nilai rata-rata $=\frac{\text { Jumlah Skor } \times 100}{\text { Skor maksimal }}$

Indikator keberhasilan Penelitian Tindakan Kelas (PTK) adalah apabila hasil belajar siswa Kelas IV SDN Rawalumbu selama proses pembelajaran mengalami peningkatan. Hal ini akan ditandai dengan daya serap individu minimal $65 \%$ dan ketuntasan belajar klasikal minimal $70 \%$ dari jumlah siswa yang ada. Ketentuan ini sesuai dengan Kriteria Ketuntasan Minimal (KKM) yang diberlakukan di SDN Rawalumbu.

Pelaksanaan tindakan dilakukan secara bersiklus dan terdiri dari empat fase yaitu Perencanaan, Pelaksanaan tindakan, Observasi, dan Refleksi.

\section{HASIL DAN PEMBAHASAN}

Kegiatan pembelajaran pada setiap siklus dalam penelitian tindakan kelas ini sebagai upaya untuk meningkatkan prestasi belajar siswa pada materi Sumber Daya Alam dan Kegiatan Ekonomi dengan menggunakan media peta dan model pembelajaran kooperatif dapat digambarkan pada laporan hasil dan pembahasan yang diuraiakan persiklus sebagai berikut:

Pada tahap Pra Siklus, Dari observasi mengenai persiapan mengajar (instrumen observasi kegiatan guru) dapat diperoleh gambaran bahwa persiapan guru dalam pembelajaran belum menggambarkan pembelajaran yang aktif, efektif, kreatif, dan menyenangkan. Kegiatan pembelajarannya belum tergambar pada persiapan mengajar. Dalam kesiapan siswa menerima pelajaran belum optimal, hal ini dibuktikan banyak siswa yang tidak membawa buku paket kelas IV. Dari hasil observasi peneliti sendiri diperoleh gambaran kegiatan pembelajaran sebagai berikut : siswa banyak mencatat materi yang dituliskan guru di papan tulis, siswa yang mengajukan pertanyaan sedikit sekali, kalaupun ada pertanyaan bukan tentang materi pelajaran, sedikit sekali siswa 
yang menjawab pertanyaan, kalaupun ada jawaban masih salah, sedikit sekali siswa yang memperhatikan penjelasan guru, walaupun mereka kelihatannya tenang, ternyata mereka tidak tertarik dengan pembelajaran yang dilaksanakan oleh peneliti, dan sedikit sekali siswa yang bersungguh-sungguh dalam mengerjakan tugas dan latihan. Dari gambaran di atas, dapat membuktikan bahwa siswa tidak aktif dan kreatif dalam pembelajaran.

Setelah pembelajaran selesai maka diajukan tes akhir. KKM untuk kompetensi dasar ini adalah 70. Setelah dilakukan analisis hasil tes dapat ditunjukkan pada tabel berikut:

Tabel 2. Hasil Tes Pra siklus

\begin{tabular}{cccc}
\hline \multicolumn{2}{c}{ Peserta Didik Tuntas } & \multicolumn{2}{c}{ Peserta Didik Tidak Tuntas } \\
\hline Jumlah & $\%$ & Jumlah & $\%$ \\
4 & 28,57 & 10 & 71,43 \\
\hline
\end{tabular}

Proses pembelajaran yang aktif dan kreatif dapat diwujudkan dengan mengoptimalkan metode, media dan model pembelajaran serta kemampuan guru dan siswa. Hasil observasi pada tahap pra siklus ini baik kegiatan guru maupun kegiatan siswa dijadikan bahan dalam menentukan tindakan selanjutnya, yaitu: persiapan mengajar yang dibuat belum menggambarkan pembelajaran yang aktif dan kreatif, kurangnya motivasi guru terhadap siswa, kurangnya media pembelajaran, alokasi waktu yang sedikit tidak seimbang dengan luasnya materi yang dipelajari, kurangnya model dan metode pembelajaran yang digunakan guru.

Berdasarkan refleksi pada pra siklus maka diputuskan untuk melanjutkan ke siklus I dikarenakan belum mencapai ketuntasan klasikal yang diharapkan. Hasil observasi proses belajar mengajar diperoleh gambaran bahwa telah terjadi peningkatan semangat dan aktivitas siswa dari yang kurang aktif bertanya dan menanggapi pertanyaan guru maupun temannya yaitu $70,45 \%$. Pada siklusi I ini guru menetapkan satu indikator pembelajaran, yaitu siswa dapat menjelaskan tenteng sumber daya alam dan kegiatan ekonomi yang ada di Indonesia. Pada siklus I ini dilaksanakan tes untuk mengukur kemajuan siswa, Persentase ketuntasan klasikalnya meningkat yaitu $64,29 \%$. Hasil nilai tersebut dapat dilihat pada tabel 2 berikut ini:

Tabel 3. Hasil Tes Siklus I

\begin{tabular}{cccc}
\hline \multicolumn{2}{c}{ Peserta Didik Tuntas } & \multicolumn{2}{c}{ Peserta Didik Tidak Tuntas } \\
\hline Jumlah & $\%$ & Jumlah & $\%$ \\
9 & 64,29 & 5 & 35,71 \\
\hline
\end{tabular}

Berdasarkan tabel di atas maka terjadi peningkatan antara pra siklus dan siklus 1 . Pada pra siklus hanya terdapat 4 anak yang sudah tuntas, tetapi pada siklus 1 bertambah menjadi 9 anak yang sudah tuntas dengan Kriteria Ketuntasan Minimal (KKM) sebesar 70. Persentase ketuntasan klasikalnya meningkat, jika pada pra siklus hanya $28,57 \%$ maka pada siklus 1 menjadi $64,29 \%$.

Analisis terhadap hasil tes tersebut menyimpulkan bahwa pembelajaran secara umum mengalami peningkatan kreatifitas guru dan keaktifan siswa. Siklus II berikutnya dilakukan untuk meningkatkan aktivitas guru dan siswa yang masih kurang, kemudian meningkatkan rata-rata hasil belajar siswa.

Setelah siklus II dari hasil observasi teman sejawat diperoleh gambaran tentang aktivitas siswa selama proses pembelajaran. Pada siklus II ini keaktifan siswa mencapai $93,18 \%$ artinya terjadi peningkatan pada aktivitas belajar siswa. Setelah dilaksanakan 
tes, hasilnya menunjukkan bahwa Persentase ketuntasan klasikalnya adalah $85,71 \%$. Hasil belajar ini dapat dilihat pada tabel 3 berikut :

Tabel 4. Hasil Tes Siklus II

\begin{tabular}{cccc}
\hline \multicolumn{2}{c}{ Peserta Didik Tuntas } & \multicolumn{2}{c}{ Peserta Didik Tidak Tuntas } \\
\hline Jumlah & $\%$ & Jumlah & $\%$ \\
12 & 85,71 & 2 & 14,29 \\
\hline
\end{tabular}

Pada siklus II ini, hasil belajar siswa kelas IV SD Negeri Rawalumbu sudah menunjukkan hasil yang baik dari sebelumnya. Pada siklus II hasil yang diperoleh sudah berada diatas rata-rata ketuntasan klasikal yang ditetapkan.

Berdasarkan hasil penelitian yang telah dilakukan menunjukkan bahwa penggunaan media peta dan gambar serta metode diskusi dalam pembelajaran khususnya mata pelajaran IPS materi sumber daya alam dan kegiatan ekonomi, dapat meningkatkan hasil belajar siswa. Pada pelaksanaan tindakan siklus I daya serap individu (skor tertinggi) sebesar 80 (6 orang siswa).nilai terendah 60 sejumlah 5 orang dengan skor rata-rata 69,28, persentase ketuntasan klasikal $64,29 \%$. siswa yang tuntas 9 orang dan yang belum tuntas sejumlah 5 orang.

Pelaksanaan tindakan siklus II sudah mengalami peningkatan. Pada siklus II ini daya serap individu atau skor tertinggi diraih oleh 3 orang siswa dengan nilai 90 dan nilai terendah diraih oleh 2 orang dengan nilai 60 . Skor rata-rata 77,86 atau meningkat $9 \%$ dari siklus I. Persentase tuntas klasikal sebesar $85,71 \%$ atau meningkat sebesar $20,81 \%$ dari tindakan siklus sebelumnya. Pada siklus II ini, siswa yang tuntas 12 orang dan yang belum tuntas 2 orang siswa. Dengan demikian, penggunaan media dan metode yang tepat pada pembelajaran dapat meningkatkan hasil belajar siswa menjadi lebih baik. Jadi, berdasarkan hasil penelitian dapat disimpulkan bahwa dengan menggunakan media peta dan gambar serta metode diskusi dapat meningkatkan hasil belajar siswa, khususnya pada materi sumber daya alam dan kegiatan ekonomi.

\section{SIMPULAN}

Dari hasil perbaikan pembelajaran dua siklus dengan menggunakan media peta dan gambar serta metode diskusi pada muatan pelajaran IPS dengan materi pokok "Pemanfaatan Sumber Daya Alam dalam Kegiatan Ekonomi" dapat meningkatkan hasil belajar siswa kelas IV SDN Rawalumbu.

Berdasarkan simpulan di atas, penulis ingin memberikan saran kepada rekan guru sebaiknya dalam kegiatan belajar mengajar, penggunaan media dan metode pembelajaran lebih ditingkatkan lagi, karena dengan menggunakan media dan metode pembelajaran, siswa akan lebih bersemangat sehingga hasil belajar lebih meningkat dan guru juga sebaiknya menguasai bermacam-macam tehnik pembelajaran, mampu menggunakan media pembelajaran tidak hanya yang tersedia di sekolah melainkan mampu menciptakan/menggunakan media pembelajaran sendiri yang ada dilingkungan sekitar, disesuaikan dengan mata pelajaran dan materi yang diajarkan.

Selain itu, Penelitian Tindakan Kelas (PTK) bertujuan untuk mengetahui dan mengatasi berbagai masalah dalam pembelajaran merupakan hal yang tepat. Dengan melakukan Penelitian Tindakan Kelas (PTK) guru akan mengetahui kelemahan dirinya dan berupaya untuk memperbaikinya serta meningkatkan kualitas pembelajaran. Di samping itu, Penelitian Tindakan Kelas (PTK) dapat meningkatkan prestasi belajar siwa.

Penulis menyarankan agar rekan-rekan guru mempelajari dan menerapkan PTK di kelas yang menjadi tanggung jawabnya. Penelitian Tindakan Kelas ini merupakan upaya guru untuk meningkatkan kualitas guru dalam pembelajaran melalui aktivitas di 
kelasnya masing-masing untuk meningkatkan prestasi belajar siswa yang pada muaranya meningkatkan mutu pendidikan.

\section{DAFTAR PUSTAKA}

Azhar Arsyad. (2011). Media Pembelajaran. Rajawali Per Jakarta

Dahlia Syuaib. (2012). Penelitian Tindakan Kelas. Edukasi Mitra Grafika.Palu

Gunawan, Rudi. (2013). Pendidikan IPS filosofi, Konsep, dan Aplikasi. Alfabeta. Bandung.

Hamdani.2011.Strategi Belajar Mengajar. Bandung: CV. Pustaka Setia.

Jensen. E. (2010). Guru Super \& Super Teaching. PT Indeks. Jakarta.

Kunandar. (2013). Penilaian Autentik (Penilaian Hasil Belajar Peserta Didik Berdasarkan Kurikulum 2013). PT. Rajagrafindo Persada.Jakarta.

Trianto. (2010). Model Pembelajaran Terpadu. Bumi Aksara. Jakarta

Wahidmurni. (2017). Metodologi Pembelajaran IPS. Ar-Ruzz Media Yogyakarta. 